\title{
Names
}

A Journal of Onomastics

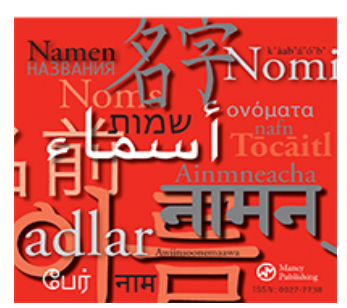

ISSN: 0027-7738 (Print) 1756-2279 (Online) Journal homepage: http://www.tandfonline.com/loi/ynam20

\section{Out-of-the-blue Names of Paint Colors}

\section{Jan Tent}

To cite this article: Jan Tent (2017): Out-of-the-blue Names of Paint Colors, Names, DOI: 10.1080/00277738.2017.1344463

To link to this article: http://dx.doi.org/10.1080/00277738.2017.1344463

$$
\text { 曲 Published online: } 16 \text { Jul } 2017 .
$$

Submit your article to this journal 준

$$
\text { LII Article views: } 1
$$

Q View related articles $₫$

$$
\text { View Crossmark data }
$$




\title{
Out-of-the-blue Names of Paint Colors
}

\author{
JAN TENT \\ School of Literature, Languages and Linguistics, Australian National \\ University, Canberra, Australia
}

Names of products play a significant role in their marketing, and are designed to express images with which buyers can identify. Manufacturers therefore pay close attention to their product names in order to maximize sales and to distinguish their products from those of competitors. The meaning of a product name would appear to be a crucial factor in its choice. A product designed for a specific consumer would benefit from a transparent or trendy name recognized and appreciated by the intended buyer. However, this tenet does not seem to apply to paint color names. Often these names tend to be enigmatic. This paper investigates the color names of 10 paint manufacturers in Australia and New Zealand. More than 10,700 color names were collected, classified, and quantitatively analyzed. The majority of names had enigmatic labels. The reasons for this are explored.

KEYWORDS paint color names, product names, marketing.

\section{Introduction}

I think the names of colors are at the edge, between where language fails and where it's at its most powerful. A.S. Byatt, The Art of Fiction No. I68

In the world of marketing, image is crucial, and part of this is the brand or product name. Since the mid-I980s, more and more academic papers in onomastics have focused on commercial and brand names (see, for example, Aronoff I98I; Boerrigter and Nijboer 20I2; Danesi 2006, 20II; Evans I967; Gutknecht and Wehking I985; Harder I999; Hernández 2013; Kremer and Ronneberger-Sibold 2007; Kurrasa, Trovatob, and Vigoloc 20I2; Miller and Kahn 2005; Nuessel 20I0, 20I4, 20I6; Piller I999; Romanova 20I6; Sjöblom 20I6; Sjöblom et al. 20I3; and Wochele et al. 20I2). Much of the recent literature emphasizes the importance of commercial names as "symbolic capital", which should be considered as resources and assets in themselves. They are "designed to convey a specific image with which consumers can identify or relate" (Danesi 2009, 47). Danesi further states that the notion of a brand image instills within a product "an identity or distinct 'personality' by giving it an appealing name" (46). 
Product names are carefully chosen to entice potential buyers, the names of paint colors included. In the world of product names, paint color names provide an intriguing field of enquiry because they are very often mystifying and frequently have naught to do with the color they are supposed to be identifying.

\section{Background Information}

\section{Naming Issues}

A number of paint manufacturers were contacted and asked about their color naming practices. Those who responded provided the following information. They sometimes name paints according to a current fashion, e.g. Avatar, Dalek, Dotcom, Fifty Shades, Hashtag, Nemo, Rivendell, or names on a theme such as Game of Thrones. The first problem with this approach is that fashions are ephemeral, and nothing is as outdated as a name associated with a bygone fashion. Secondly, there is always the danger of copyright or trademark infringement.

Then there are names which, when introduced, are innocuous, but later obtain negative connotations. For instance, one paint manufacturer has a longstanding color called Ash Wednesday. However, this became a sensitive name after a series of bushfires on I6 February 1983 (i.e. the first day of Lent, more popularly known as "Ash Wednesday") struck in south-eastern Australia. The fires were dubbed the Ash Wednesday Fires, and was one of the most costly natural disasters in Australian history-some 3700 buildings were destroyed, 2545 people lost their homes, and 75 people lost their lives. Calls have been made to change this color name; however, the manufacturer argues the name existed long before the fires, and was based on the name for the first day of Lent. The name remains on their main list of colors but is not in the current retail range.

Punch Me was a color name that backfired and caused criticism from the LGBTQIA community who claimed pink was a color often associated with them, and women in general, and the name was in effect suggesting that these people were to be subjected to violence. ${ }^{\mathrm{I}}$ A complaint to the company promptly saw the name withdrawn (see Domingue 20I0; MacGregorm 20I0). In a similar vein, the color name Gaytime-named after a well-known ice cream product - attracted opprobrium from the same community. The ice cream company also objected on the grounds of trademark infringement, and the color name was removed. Interestingly, the color name Iced Vovo-named after a popular brand of biscuit with pink and red marshmallow topping sprinkled with desiccated coconut - has not attracted the ire of the biscuit manufacturer, perhaps because they see it as a convenient bit of advertising.

The paint manufacturers contacted also endeavor to avoid puns and humorous names, however, some do appear, e.g. Blue By You, Burple, Elemint, Greige (grey+beige?), Maliblue, Marsh Meadow, and Peak A Blue. Sjöblom (2016, 459) notes that such deviations of spelling and grammar are considered attractors (see Kremer and Ronneberger-Sibold 2007, I8I-82), and are a deliberate marketing ploy. The manufacturers also reported they try to avoid misleading suggestive names, however Black Ace (a grey), Black Drop (a light blue), Diamond White (a grey), and Viagra (not a blue but a yellow) are still to be found in color catalogs.

One paint manufacturer runs an annual competition with staff-and occasionally with customers - giving them a chance to suggest color names. These are then added 
TABLE 1

MILLER AND KAHN COLOR/FLAVOR NAME TYPOLOGY $(2005,91)$

\begin{tabular}{lll}
\hline & Atypical & Typical \\
\hline Unspecific & Ambiguous & Common \\
Specific & Unexpected Descriptive & Common Descriptive \\
\hline
\end{tabular}

to the master list of color name ideas. This company currently has around Io, ०0० ideas on the list, though not all are suitable for color names, and will ultimately be discarded. This manufacturer also names paint colors targeted at children's rooms and furnishings etc. after things that relate to children or that children would relate to, e.g. Snuggle Pot and Cuddle Pie (two characters from a famous Australian children's story), Hide And Seek, My Favourite, Pink Dolly, and Space Capsule. Their wood stain colors, on the other hand, tend to have more traditional and natural/nature-inspired names such as Cedar, Jarrah (a native Australian tree), Mahogany, Walnut, etc. This same company normally pre-selects some preferred color names and then matches them to the colors that need to named, based on which color names fit the "personality" of the color. ${ }^{2}$ They find reds, oranges, and yellows are typically the easiest to name, claiming that "these colors tend to have very strong personalities and energy which makes it easier to find a catchy name for them". Greens and browns are found to be the most difficult to name because there is a tendency to bestow them with names to do with nature, which is not considered to be very imaginative, although it is difficult to see why this is problematic, given the logic behind such names.

Color names that comprise two colors, e.g. Fawn Beige, Gold Buff, Grey Beige, Orange Vermillion, Taupe Grey, etc. are not necessarily named after their color composition. Often the naming is relative to the colors around it on the spectrum of colors in the catalog. For instance, a beige may be greyer than the one beside it, or compared to another beige somewhere else it may actually have a grey tone.

In short, none of the manufacturers contacted seem to follow any hard and fast rules in naming colors, with the exception perhaps of names that have already been used, either by themselves or a competitor. Also, once a name has been chosen, it is checked against existing colors to avoid the new name being too similar to existing ones. ${ }^{3}$

\section{Previous Color Typologies}

Harder $(1999,245)$ notes, color names "do not categorize easily, for they are concerned with things and emotions together". ${ }^{4}$ In other words, they may vary from the logical and transparent to the very arbitrary and semantically opaque. In his paper on color names, Harder categorizes color names under the following groupings:

- plant names

- color substitutes involving colors of fruits, nuts, bark, or foliage

- animals, fowl, and fish

- faunal partials (e.g. such as Pigeon's Blood, Oxheart)

- toponyms

- native American names

- major places of education 
- military standard colors

- religious vocabulary

- minerals and chemicals, including dyes

- classical names

- the pantheon Greek and Roman of gods

- liquors and wines

- eponyms

- artist and literary names

- dance related names

- miscellaneous

The mélange of paint color names found in paint catalogs is fittingly represented in Harder's rather random list. Zelinsky (2002), although discussing toponyms, rightly warns against such typologies, declaring them definitional morasses that are interminable. Harder's list reflects this interminability, because it is predisposed to the addition of endless new categories. Zelinsky further appeals for the systematic "cataloguing and arranging [of] all the objects under investigation into some logical, coherent classificatory scheme" (248). This is precisely what is needed for paint color names. For such a typology to be effective it needs to have enough specific categories to cover all types of color name, whilst revealing the distinctions in their naming motivation. ${ }^{5}$ Secondly, the categories must be mutually exclusive. Harder's categories are not-there is a large degree of overlap between a number of them. Thirdly, an efficacious typology must also be flexible enough to allow for additions of categories without causing fundamental structural changes to the overall schema. In addition, it ought to permit color names from different eras and regions (both international and national). Harder's Native American category is therefore too specific and parochial.

Sjöblom (20I6, 46I) echoes Zelinsky's warning and adds that "onomasticians examine names formally by lexically dividing their components into different semantic groupings". However, like Harder's list such groupings make it more difficult to create an effective typology, because the semantic groupings are likely to be boundless.

In a study on the effect of color and flavor names on consumer choice, Miller and Kahn (2005) employed a 2X2 framework for categorizing names. It is based on a color/ flavor name's conformity and specification (i.e. portrayal). Conformity is graded into whether a name is typical or atypical; specification is graded as specific and unspecific. The four resulting categories are:

- Common (typical, unspecific)-e.g. Light Ginger, Pale Blue, Scarlet

- Common Descriptive (typical, specific)-e.g. Lemon Yellow, Pine Green, Sea Green $^{6}$

- Unexpected Descriptive (atypical, specific)-e.g. Kermit Green, Shadowy Blue

- Ambiguous (atypical, unspecific) - e.g. Abacus, Cargo, Wham, Puerto Rico

This simple typology (represented in Table $\mathrm{I}$ as a $2 \times 2$ framework) proved to be effective in their study, so after some initial trials a slightly revised version was employed for the current study. 


\section{The Study}

This study deals with the color names of paints available in Australia and New Zealand. The names were downloaded from the websites of ro of the main paint brands on the market, six of which belong to two companies (three each), the other four being independent companies. One manufacturer is a New Zealand-based company. The color names were categorized, and a quantitative analysis conducted on the various categories into which they were classified.

The Io paint manufactures belong to international and local companies. The international companies, though having color names used in other countries, also have locally produced colors with local names. The local paint manufacturers tend to be small, one being a family-owned company. All local offices of the ro companies were contacted and information sought on their color naming practices. Only four responded to the request. In three of the companies color naming was conducted by a committee of two or four individuals; in the fourth the responsibility lay with a specially designated senior technical officer. Each company had its own procedures for naming, although they were generally quite loose.

A total of I0,722 color names were recorded and categorized. Many colors in the online catalogs have eighth, quarter, half, double, and triple tones, e.g. Eighth Dutch White, Quarter Bison Hide, Half Canterbury Clay, Double Pearl Lusta, Triple Parchment. These names were excluded from the datasets, being considered as virtual duplicate names.

As mentioned above, the Miller and Kahn (2005) typology was adopted with a change in category labels. The structure of and reasoning behind the Miller and Kahn typology was retained, while the label "Ambiguous" was modified to "Enigmatic" to better reflect the perceived nature of these color names. "Ambiguous" has the sense of two or more possible meanings that seem to be apparent, whereas "Enigmatic" has the sense of "no discernible meaning", which is most often the case. For instance, color names such as Colossus (a purple), Guitar (a dark brown), Jules (a red), Morpheus (a dark grey), and Radar (a blue), are cryptic and provide no clue as to their actual hue.

"Orthodox" was used rather than "Common" to better reflect the accepted, traditional, conventional, or standard nature of these color names. The term "Common" simply does not seem to capture this sense, which is the one that Miller and Kahn most likely intended. The term "Unexpected" carries with it the notion of surprise. Many of the color names in this category are not surprising, but understandable, like Bayleaf Brown, Kermit Green, Stingray Grey, and Uluru Red (Uluru being the famous large red sandstone rock formation in central Australia). The term was replaced by "Unorthodox", which also suitably contrasts with the label "Orthodox". The revised typology labels for the present study are listed in Table 2 .

TABLE 2

COLOR NAME TYPOLOGY BASED ON MILLER AND KAHN $(2005,91)$

\begin{tabular}{lll}
\hline & Atypical & Typical \\
\hline Unspecific & Enigmatic & Orthodox \\
Specific & Unorthodox Descriptive & Orthodox Descriptive \\
\hline
\end{tabular}


TABLE 3

CATEGORIES OF PAINT COLOR NAME FOR EACH PAINT BRAND

\begin{tabular}{|c|c|c|c|c|c|c|c|c|c|}
\hline \multirow{3}{*}{$\begin{array}{l}\text { Paint } \\
\text { Brand }\end{array}$} & \multirow{3}{*}{$\begin{array}{c}\text { Number } \\
\text { distinct } \\
\text { color } \\
\text { names }\end{array}$} & \multicolumn{8}{|c|}{ Category } \\
\hline & & \multicolumn{2}{|c|}{ Enigmatic } & \multicolumn{2}{|c|}{ Orthodox } & \multicolumn{2}{|c|}{$\begin{array}{l}\text { Unorthodox } \\
\text { Descriptive }\end{array}$} & \multicolumn{2}{|c|}{$\begin{array}{c}\text { Orthodox } \\
\text { Descriptive }\end{array}$} \\
\hline & & Freq. & $\%$ & Freq. & $\%$ & Freq. & $\%$ & Freq. & $\%$ \\
\hline$\overline{M_{1}}$ & 1833 & 1121 & 61.1 & 12 & 0.7 & 666 & 36.3 & 34 & 1.9 \\
\hline M2 & 471 & 278 & 59.0 & 12 & 2.6 & 162 & 34.4 & 19 & 4.0 \\
\hline$M_{3}$ & 502 & 257 & 51.2 & 2 & 0.4 & 226 & 45.0 & 17 & 3.4 \\
\hline M4 & 779 & 540 & 69.3 & 4 & 0.6 & 204 & 26.2 & 31 & 3.9 \\
\hline M5 & 1122 & 607 & 54.1 & 60 & $5 \cdot 3$ & 322 & 28.7 & 133 & 11.9 \\
\hline M6 & 163 & 65 & 39.9 & 8 & 4.9 & 71 & 43.5 & 19 & 11.7 \\
\hline M7 & 382 & 227 & 59.4 & 15 & 3.9 & 127 & 33.3 & 13 & 3.4 \\
\hline M8 & 2800 & 1885 & 67.3 & 136 & 4.9 & 663 & 23.7 & 116 & 4.1 \\
\hline M9 & 1384 & 854 & 61.7 & 5 & 0.4 & 502 & 36.2 & 23 & 1.7 \\
\hline M10 & 1286 & 813 & 63.2 & 23 & 1.8 & 393 & 30.6 & 57 & 4.4 \\
\hline Totals & 10722 & 6647 & 62.0 & 277 & 2.6 & 3336 & 31.1 & 462 & $4 \cdot 3$ \\
\hline
\end{tabular}

\section{Results}

The results of the count and analysis is presented in Table 3. As can be seen, the vast majority of paint color names are Enigmatic $(62 \%)$ followed by half as many Unorthodox Descriptive (3I.I \%). Very few paints bear an Orthodox name $(2.6 \%)$ or are Orthodox Descriptive $(4.3 \%)$. Given the commercial motivations in naming colors, this is not surprising. The latter types of names tend to be repetitive, uninspiring, and there is a much greater chance of duplicating names from competitors. Nonetheless, two manufacturers $\left(\mathrm{M}_{4}\right.$ and $\mathrm{M}_{5}$ ) have almost $\mathrm{I}_{2} \%$ of their color names in the Orthodox Descriptive category, considerably more than the others. It was found that $6.5 \%$ of names in the total data-set were duplicates (i.e. the same name used by two or more manufacturers). Not surprisingly, these were largely Orthodox or Orthodox Descriptive names.

Many of the paint colors in the data-set can be found in Kelly and Judd's (I976) Color: Universal Language and Dictionary of Names, which lists some 7,500 color names, and includes the ISCC-NBS method of designating colors. However, the dataset also includes numerous color names used specifically in the Australian and New Zealand paint market. Many of these names are Australian and New Zealand terms and echo local flora, fauna, and culture. The spelling of these names also adheres to local spelling conventions (i.e. US spellings are avoided). Among the Australian names are: Anzac (an iconic and copyrighted national acronym Australian and New Zealand Army Corps), Bandicoot (k.o. marsupial), 7 Banksia Leaf (k.o. tree), Bass and Flinders (two of Australia's best-known early explorers), Billabong (a river branch that forms a backwater), Bilby (k.o. marsupial), Didgeridoo (Aboriginal musical instrument), Echidna (k.o. monotreme), Flooded Gum (k.o. eucalyptus tree), Galah (native pink and grey parrot), Pharlap (name of Australia's most famous racehorse), She'll Be Right (expression meaning "it will be okay"), True Blue (an expression meaning "genuine Australian”), ${ }^{8}$ and Waratah (k.o. red native flower).

From New Zealand emanate names such as: Dark Rimu (k.o. timber), Kakapo (k.o. parrot), Koru (symbol in Māori art based on the shape of an unfurling silver fern frond), 
Manuka Honey (honey from the Manuka flower), Pukeko (Australasian Swamp Hen known for its bright purple throat and breast), and Tuatara (k.o. lizard).

As would be expected, toponyms also feature prominently in both countries' paint names: Ayers Rock (now better known as "Uluru"), Barossa, Bogong, Botany Bay, Daintree, Kakadu, Neutral Bay, ${ }^{9}$ Noosa, St Kilda, and Sydney Harbour, all of which are iconic or historic names in Australia. Toponymic names from New Zealand include: Haast Shale, Hokonui, Milford Green, Piha Sand, Rangitoto, Tarawera, and Wanaka, once again all iconic names that are likely to evoke positive reactions. Interestingly, none of these toponymic color names (with the exception perhaps of Ayers Rock) are suggestive of any particular hue.

The majority of names in the data-set $(62 \%)$ are so opaque (i.e. Enigmatic) as to leave the potential paint purchaser scratching their head as to the connection between the color and its designated name, for example: Alcatraz, Anonymous, ASAP, Attitude, Dream I Can Fly, Drop Dead Gorgeous, Enigma, Full Monty, How Now, Hugo, Hugs \& Kisses, Lexicon, Longitude, Meniscus, Mexican Standoff, Monastic, Pragmatic, Rumour Has It, Shutterbug, Tip Toes, Twentyfourseven, and Wot Eva (indeed!).

Some other trends in color names found in the data-set include ${ }^{\text {Io }}$ :

- Standard expressions/sayings (many with a homely, positive, feel-good connotation): Barely There, Basic Instinct, Catch 22, Daddy's Girl, Deep Blue Sea, Good As Gold, Home Grown, How Sweet It Is, It's A Boy, Oh Boy, Out Of The Blue, Peas In A Pod, Pretty Please, Rise And Shine, Wow, and Young At Heart. Classified as either Enigmatic or Unorthodox Descriptive names.

- Suggestive names: Afternoon Storm (a grey), Chlorophyll (a green), Cloudy Winter (a grey), Night Sky (a dark blue), Salmon Run (a red), Sunburnt Nose (a red), and Twist Of Lime (a green). Classified as Unorthodox Descriptive names.

- Oxymoronic names (rare, for obvious reasons): Black Light, Black White, Blue Charcoal, and Ice Hot. Classified as Unorthodox Descriptive.

- French and pseudo-French color names (to add a touch of class to what would otherwise be an uninspiring name?): A La Orange, Entre Sol, Le Fleur, Le Mer, Rouge. ${ }^{\text {II }}$ A mixture of Orthodox, Orthodox Descriptive, and Unorthodox Descriptive names.

- Tautologous names: Burnt Charcoal, Ultramarine Blue. Classified as Orthodox Descriptive or Unorthodox Descriptive names.

- Unappealing names (strange compounds and names with a negative connotation): Bordello, Bridal Wreath (apart from being a plant name, it could have rather funereal connotations to many), Chain Gang, Crown Of Thorns (apart from being a plant name it also refers to a large, very ugly, multiple-armed starfish with venomous spines that preys upon hard coral), Drab, Drought, Grass Stain, Off Yellow, Sunburnt Nose, and Wolf Creek (the name of an Australian horror movie). Classified under one of the four categories.

- Lackluster names (ones that show little or no imagination): Blast Grey I, Blast Grey 2, and Blast Grey 3. Classified as Unorthodox Descriptive.

The final two groups can hardly be considered very suitable names from a marketing point of view. However, with perhaps the exception of the pseudo-French names, the rest may be considered as forms of attractor (see above). 


\section{Discussion}

The obvious question that arises is, why are so many color names Enigmatic or Unorthodox Descriptive? Such names are often too obscure to extract any meaningful sense from them. Of course, no potential buyer merely chooses a paint color by its name; it is the actual hue on a color card that is probably the primary motivating factor. Its name merely functions as a unique identifier, which is then matched with a code, which subsequently provides the correct mixture to make up the desired color.

As mentioned above, product names play a vital role in marketing and are used to associate the product with a brand or manufacturer. Paint color names are no different. A paint manufacturer does not want its colors bearing the same names as those of a competitor. The more distinct and exotic a paint name, the more likely it is to be recognized and identified with a particular paint brand. Sjöblom $(2016,456)$ notes: "Commercial objectives are of course most important when names are being invented. Naming is part of business communication. [...] People tend to buy products which have personality, an image that speaks to them." This is the motivating factor that lies behind the choice or creation of a color name.

Although many scholars in onomastics and marketing have shown that the meanings of product names also play an important role in marketing (see, for instance, Danesi 2006, 2009, 20II; Nuessel 20I0, 20I4, 20I6), meanings seem to play less of a role in paint color names. This is shown by Miller and Kahn (2005). Through a series of experiments they found participants reacted more favorably to unusual (i.e. Enigmatic or Unorthodox Descriptive) color or flavor names than to those which had Orthodox or Orthodox Descriptive names. This finding seems contrary to what one expects. A marketer's aim in promoting a product is to communicate a clear and unambiguous message. However, this tenet may not apply to paint color or flavor names. Miller and Kahn found that when the name was not informative or did not conform to expectations, participants in their experiments sought a reason for the deviation.

Miller and Kahn explain this phenomenon in terms of Grice's (1975) "cooperative principle", and "incongruency theory" (see Heckler and Childers I992). Inconguency theory states that people make communicative judgments by evaluating new information against prior expectations. When a message is incongruent with expectations, people will expend more effort in processing or analysis to resolve the incongruency. Mandler (I982) claims congruent items (those consistent with or matching our expectations) will generate marginally positive responses for no resolution is required. However, a modest degree of incongruity will lead to broader processing in an attempt to resolve the incongruity. This degree of incongruity can make items appear more appealing and lead to more positive judgments. If nothing else, it will make the objects more memorable because of the cognitive disjoint.

Applied to the context of paint color names, these theories suggest "that when consumers encounter an unfamiliar name that is counter to their expectation that the marketer would be providing a familiar name, they try to determine how the adjective describes the color" (Miller and Kahn 2005, 87).

By employing the cooperative principle and the inconguency theory, Miller and Kahn $(2005,87)$ hypothesized 
that consumers may assume that all information offered to them by the marketer is meant to be relevant or informative and they will consequently try to make sense of it. If the ambiguous name is uninformative in the literal or semantic sense, consumers will search for a pragmatic meaning or reason for the communication.

Enigmatic paint names communicate little to the consumer in terms of the color itself, and when such names are encountered, the potential buyer will search for a pragmatic reason for the name. Sjöblom (20I6, 46I) puts it another way: "While word-plays require more processing effort from the recipient, it can produce special joy when understood."

\section{Conclusion}

The potential range of paint colors is infinite, yet all are created by mixing a small set of base colors-whites and neutrals, greys and blacks, browns, purples, blues, greens, yellows, oranges, and reds. The language used to describe the multitude of possible hues is limited by our lexicon of color terms. Simply employing basic color terms to describe new hues would not only be tedious but would introduce much duplication in color names. This manufacturers want to avoid in order to keep their range of colors and names distinct. It is very doubtful whether paint manufacturers are cognizant of Grice's cooperative principle and the incongruency theory and employ them in their color naming. This notion is indirectly supported by Miller and Kahn (2005, 9I) who suggest that researchers, although having shown these norms are followed in normal conversational settings, have not yet demonstrated that they "also play a role in marketing communications". If they had, marketers perhaps would have embraced these theories.

The information gleaned from the four paint manufacturers does not allude to any conscious effort in bestowing Enigmatic or Unorthodox Descriptive names to paint hues because of an awareness of the effects of the cooperative principle and the incongruency theory. On the contrary, new names are bestowed on new paint hues so that they are distinct from those of competitors, and our limited color lexicon forces manufacturers to search further afield to more exotic and unusual names. That the consumer may be more attracted to such names because they are obeying the cooperative principle is a windfall for the manufacturer.

If Miller and Kahn are correct, it is perhaps worth concluding with the words of Ries and Trout (I98I, 7I) which are conceivably equally applicable to paint color names:

Shakespeare was wrong. A rose by any other name would not smell as sweet. Not only do you see what you want to see, you also smell what you want to smell. Which is why the single most important decision in the marketing of perfume is the name you decide to put on the brand.

\section{Acknowledgments}

I should like to thank David Blair and Iman Nick for reading and commenting on a draft of this article. My thanks also to staff of the four paint manufacturers who responded to my enquiries regarding their color naming practices. Finally, my gratitude must also go to the anonymous reviewers. All errors and omissions are mine. 


\section{Notes}

r. LGBTQIA "Lesbian, Gay, Bisexual, Transsexual, Queer, Intersex, Asexual”. For an explanation of these terms see < http://www.abc.net.au/news/20I6-04-o7/ sexuality-gender-glossary-definitions/7287572>.

2. It is unclear as to what the "personality" of a color is.

3. Company officers contacted admitted to having databases of color names from their competitors.

4. It is unclear what is meant by "things and emotions".

5. The latter may not be possible, because the color name may be too opaque to provide any hint of its naming motivation.

6. In other words, metonymical names.
7. k.o. "kind of".

8. This is clearly a pun on the color blue and the expression of Australian genuineness.

9. This is a nicely ambiguous name. It could refer to a very salubrious and upmarket harborside suburb and bay in Sydney, or it could refer to a neutral shade of the color bay.

г. These categories should not be seen as subcategories of the typology employed.

${ }^{\text {II. }}$ It is interesting to see that few of these companies get their French grammar correct. Is this done consciously?

\section{Disclosure statement}

No potential conflict of interest was reported by the author.

\section{Bibliography}

Aronoff, Mark. I98I. Automobile semantics. Linguistic Inquiry I2: 329-347.

Boerrigter, Reina, and Harm Nijboer, eds. 20I2. Names as language and capital: Proceedings names in the economy III, Amsterdam, II-I3 June 2009. Amsterdam: Meertens Instituut. <http://depot.knaw.nl/I2899/>

Danesi, Marcel. 2006. Brands. New York, NY: Routledge.

Danesi, Marcel. 2009. Dictionary of media and communications. Armonk, NY: M. E. Sharpe.

Danesi, Marcel. 20II. What's in a brand name? A note on the onomastics of brand naming. Names: A Journal of Onomastics 59: I75-I85.

Domingue, Rebecca. 20Io. Bigoted housepaint? Taubmans needs to explain this! Equal Love Armidale. <https:// equallovearmidale.wordpress.com/2010/II/o3/bigoted-housepaint-taubmans-needs-to-explain-this/> (accessed II March, 20I7).

Evans, Joseph C. 1967. Some current American pencil names. Names: A Journal of Onomastics 15: 32-38.

Grice, Paul. 1975. Logic and conversation. In Syntax and semantics, Vol. 3 speech acts, ed. Peter Cole and Jerry L. Morgan, 4I-58. New York, NY: Academic Press.

Gutknecht, Christoph, and Erwin Wehking. 1985. Produktnamen. Eine Eigene Subklasse Konkreter Substantive? [Product names. A subclass of concrete nouns?]. International Journal of Applied Linguistics 67, no. 68: 77-89.

Harder, Kelsie B. I999. A medley in the spectrum: Color names. Names: A Journal of Onomastics 47: $243^{-248}$.

Heckler, Susan E., and Terry L. Childers. 1992. The role of expectancy and relevance in memory for verbal and visual information: What is inconguency? Journal of Consumer Research I8: 475-492.

Hernández, Lorena Pérez. 2013. A pragmatic-cognitive approach to brand names: A case study of Rioja Wine brands. Names: A Journal of Onomastics 6I: 33-46.

Kelly, Kenneth Low, and Deane Brewster Judd. 1976. Color: Universal language and dictionary of names. Washington, DC: U.S. Dept. of Commerce, National Bureau of Standards.

Kremer, Ludger, and Elke Ronneberger-Sibold, eds. 2007. Names in commerce and industry: Past and present. Berlin: Logos.

Kurrasa, Paola Cotticelli, Alfredo Trovatob, and Vania Vigoloc. 20I2. Brand name and brand image between linguistics and marketing. In Names as language and capital: Proceedings names in the economy III, Amsterdam, II-I3 June 2009, ed. Reina Boerigter and Harm Nijboer, I3-3I. Amsterdam: Meertens Instituut. <http://depot.knaw. nl/I2899/> (accessed March 9, 2017).

MacGregorm, Bayne. 20Io. Taubmans offensive paint to be renamed. Equal Love Armidale. $<$ https://equallovearmidale. wordpress.com/20Io/II/Io/taubmans-offensive-paint-to-be-renamed/> (accessed March II, 20I7).

Mandler, George. I982. The structure of value: Accounting for taste. In Affect and Cognition: The I7th Annual Carnegie Symposium on Cognition, ed. Margaret Sydnor Clark and Susan T. Fiske, 3-36. Hillsdale, NJ: Erlbaum.

Miller, Elizabeth G., and Barbara E. Kahn. 2005. Shades of meaning: The effect of color and flavor names on consumer choice. Journal of Consumer Research 32: 86-92. 
Nuessel, Frank. 20I0. A note on names for energy drink brands and products. Names: A Journal of Onomastics 58: IO2-IIO.

Nuessel, Frank. 20I4. A note on the brand names for 'bath salts'. Names: A Journal of Onomastics 62: 49-56.

Nuessel, Frank. 20I6. A note on selected brand names of E-Cigarettes. Names: A Journal of Onomastics 64: 4I-49. Piller, Ingrid. 1999. Variation in automobile naming. Names: A Journal of Onomastics 47: 83-IO.

Ries, Al, and Jack Trout. I98r. Positioning: The battle for your mind. New York, NY: McGraw-Hill.

Romanova, Tatiana P. 20I6. Marketing message components in commercial naming. Voprosy onomastiki [Problems of Onomastics] I3: I40-I5O.

Sjöblom, Paula. 2016. Commercial names. In The Oxford handbook of names and naming, ed. Carole Hough, 453-464. Oxford: Oxford University Press.

Sjöblom, Paula, Terhi Ainiala, and Ulla Hakala. 2013. Names in the economy: Cultural prospects. Newcastle: Cambridge Scholars.

Wochele, Holger, Julia Kuhn, and Martin Stegu, eds. 20I2. Onomastics goes business: Role and relevance of brand, company and other names in economic contexts. Berlin: Logos.

Zelinsky, Wilbur. 2002. Slouching toward a theory of names: A tentative taxonomic fix. Names: A Journal of Onomastics 50: 243-262.

\section{Notes on contributor}

Jan Tent is a retired academic and current Director of the Australian National Placenames Survey. He is also an Honorary Senior Lecturer at the Australian National University, Canberra. Jan's onomastic research has mainly concentrated on early European place-naming practices in Australasia, as well as the toponymy of Australia in general. Correspondence to: Dr Jan Tent, School of Literature, Languages and Linguistics, College of Arts and Social Sciences, Australian National University, Canberra 2ro9, Australia.Email: jan.tent@anu.edu.au or director@anps.org.au 